\title{
Implementation of Performance Management in Inspectorate General of the Ministry of Law and Human Rights
}

Joko Martanto

Doctorate Student, Human Resource Management

The State University of Jakarta, Indonesia

E-mail: Jokomartanto05@gmail.com

Hady Efendy (Corresponding Author)

Education Practice and Academic Consultant

E-mail: efendy_hady@yahoo.co.id

Received: Oct. 24, 2017 Accepted: Nov. 1, $2017 \quad$ Online published: Dec. 4, 2017

doi:10.5296/ijhrs.v8i1.12043ＵRL: https://doi.org/10.5296/ijhrs.v8i1.12043

\begin{abstract}
This research is conducted on the basis that the success of achieving the goals of a company required an effective management, efficient and have the competitiveness in managing human resources owned. Through implentasi good performance management, the company can manage the performance of human resources owned so that it can work optimally and can achieve the desired goals. Efforts Inspectorate General of the Ministry of Law and Human Rights in order to create effective and efficient performance management, which is competitive and can support productivity is by applying a competency-based performance management system. The purpose of this research is to explain the implementation of the competency-based performance management system in the Inspectorate General of the Ministry of Human Rights, and to analyse and explain the supporting factors and inhibiting the implementation of competency-based performance management system in the Inspectorate General of the Ministry of Law and Human Rights. The research method used in this research is descriptive qualitative. The results of this study indicate that the implementation of competency-based performance management system in the Inspectorate General of the Ministry of Law and Human Rights is included in the pattern of management of Human Resources Management Based on Competence (MSDMBK).
\end{abstract}


Keywords: performance management system, competence, competency based human resource management, key performance index

\section{Introduction}

Facing the era of increasingly tough global competition today, every organization is required to be able to provide performance that can be implemented in all lines, and can be seen from the environment that supports it or receive benefits. With the changes and culture that is always dynamic then the environment of an organization is required to be able to provide satisfaction for the interests of various stakeholders. In this case, in addition to meeting the needs of its customers, the organization must consider the interests of both internal and external which includes the structure and system that has been done and human resources. It cannot be denied that the external environment can affect the success of organizations such as, society, government and other environments, for it needs a reliable management in deciding a strategy for the organization to achieve goals as planned by management. Management can be defined as a process of planning, organizing, leading and overseeing the work of member organizations and using all available organizational resources to achieve clearly stated organizational goals.

Seeing the condition of management then, an organization must have the ability to manage performance as well as prepare human resources and managers responsible for organizational performance and management of this performance required clear and measurable strategies and goals. To be able to produce a strong organization performance it cannot run alone in management but must synergize both individually and in groups that is by applying some realistic achievements of several levels of performance that work within the organization. The organization has been running, it is necessary to evaluate whether it is continuous evaluation in organization and evaluation that directly impact the society, group, and individual, which is a separate concept, but interrelated, the performance of an organization must be optimal in achieving the objectives.

The nature of performance management is how to manage all organizational activities to achieve organizational goals to be useful. The benefits of performance management are not only to benefit the organization but also to managers and individuals. Benefits to the organization, is performance management can adjust organizational goals with team and individual goals, improve performance, motivate workers, increase commitment, and support the valuesthat have been set. For managers, the benefits of performance management include striving and enhancing human resource behavior, offering quality time opportunities, improving team and individual performance, and so on. As for the individual, it is to clarify roles and objectives, encourage and support for better performance, assist in the development of capabilities and performance, basic objectivity and honesty. According to Costello (1994) performance management is the foundation and driving force behind all organizational decisions, work effort and resource allocation.

In reality, the current government organization is still in the spotlight because it is still not as expected although reforms have been rolled out to improve performance. Today companies or organizations face many challenges and changes happen so quickly and sometimes 
unexpectedly. These changes also occur in government-oriented governmental organizations. There have been a number of occurrences that illustrate the weakness of organizations such as poor service, some civil servants of state officials who are affected by corruption cases, rampant charges in providing services and other cases that make public confidence in the government less. Based on the road map of bureaucratic reform 2015-2019 there are still many organizational challenges that must be addressed are:

1. Bureaucracy has not been completely clean and accountable.

2. Bureaucracy has not been fully effective and efficient.

3. Public services still do not have the expected quality.

The existence of a challenge then makes a government organization must change with service-oriented rather than served, because by providing good service then public confidence in the government will increase. Therefore, it is necessary to improve and improve the role of human resources that is reliable especially for civil servants of state and organization through good policies and strategies through:

1. Building transparency and accountability of government performance, including improved management system and performance reporting, implementation of e-Government and open government.

2. Improving and improving the quality of National Bureaucratic Reform (RBN), including restructuring of government bureaucratic institutions, Strengthening the capacity of national bureaucracy reform management, through strategy, applying the management of state civil apparatus through strategy, improving the quality of public services.

This also happens to the Inspectorate General unit of the Ministry of Law and Human Rights which is one of the first echelon units in the Ministry of Law and Human Rights in which an organization is expected to create and implement a strategic plan in determining what goals will be achieved and can be measured with certainty through the Vision and Mission of the organization. Inspectorate General of the Ministry of Law and Human Rights in carrying out its duties and functions to supervise 11 units of Echelon I and 33 Regional Offices within the Ministry of Law and Human Rights and about 750 units of work in prisons and immigration units. The supervisory activities are focused on guarding activities to guard and improve performance appraisal, financial reports with WTP Opinion, increasing this work as a region free from corruption, and the index of service to the community increases.

The Inspectorate General has a paradigm of Watc Dog to be a quality assurance in which the inspectorate general is positioned as a partner to achieve organizational goals. In achieving the objectives as a supervisory apparatus is required human resources that can provide solutions for other units and required a competent supervisory resources in the field. But in reality there are still some weaknesses both in the internal organization and in performing performance such as performance that has not been measured, still overlapping and performance evaluation that has not been measured. The performance of supervision requires reliable management, in order that the results obtained or the performance of the workers or employees can achieve results addressed by the company or organization. This change requires the organization to change all the habits that have been done so far to face a high 
level of competition and to achieve the desired goals so that performance on unit one with other units must be measurable well for it needed a new approach in evaluating employee performance through performance management. By implementing performance management it will provide benefits for the organization, team, and individuals and society.

\section{Methodology}

\subsection{Types of Research}

The type of research used is descriptive research with qualitative approach. Where the researcher describes how the implementation of competency-based performance management system at Inspectorate General of Ministry of Law and Human Rights. According to Moleong (2007) descriptive research is "research containing data citations to give a description of the presentation of research reports". The excerpts of the data presented are the result of interviews, field notes, personal documentation, notes or memos and other official documents. The origin of the data can be information about all matters relating to the implementation of a competency-based performance management system.

The implementation of qualitative research according to Miles \& Huberman (1992) is "research that comes from a broad and well-defined description, and contains an explanation of the processes occurring within the local scope". With qualitative research the data obtained can follow and understand the flow of events chronologically, assess causality in the sphere of the minds of the local people, and obtain a rich and useful explanation.

\subsection{Research Focus}

The focus of this research are:

1. Implementation of Competency Based Performance Management System in Inspectorate General of Ministry of Law and Human Right, covering: a. Performance Planning b. Communication Performance, Guidance, and Documentation c. Performance Evaluation and Evaluation d. Concept of Competency Application in Performance Management System.

2. Factors supporting the implementation of Competency Based Performance Management System in the Inspectorate General of the Ministry of Law and Human Rights.

3. Factors inhibiting the implementation of Competency Based Performance Management System in the Inspectorate General of the Ministry of Law and Human Rights.

\section{Literature Review}

\subsection{Definition of Organizational Performance Management}

Successful organizations are organizations that have the will to change especially on their human resources that must be innovative and as agents of change continuously, forming processes and cultures that together improve the ability of organizational or corporate change. In an organization human resources must be managed properly in which the managers are focused on how to manage HR performance in order to achieve organizational goals are envisaged in the strategic plan of the organization. One of the concepts that are now being 
considered to be applied by various companies or organizations to control and improve performance is Performance Management System.

Performance management includes activities that ensure that goals are consistently achieved in an effective and efficient manner. Performance management can focus on broad organizational performance, then ministries / departments, employees, or even in the process of building and developing a product or service or service, and so on. By definition, performance management or performance management is a systematic process for improving organizational performance by developing individual and team performance and is a means to get better results by understanding and managing performance within an agreed framework of planned goals, standards and requirements (Armstrong, 2009).

This understanding is more focused on the process in a systematic way to get better performance. Here is a definition of performance management from several sources, among others, as follows:

1. According to Armstrong \& Murlis (2009), performance management is a means to get better results from organizations, teams, individuals within an agreed framework in planning goals, objectives and standards.

2. According to lockett (1992), the essence of performance management is the development of individuals with competence and commitment, working toward achieving shared goals in objectives within organizations that support and encourage their achievement.

3. According to DeNisi (2000), performance management is a range of organizational practices that are bound to improve the performance of a target person or group with the ultimate goal of improving organizational performance.

Based on definitions can be concluded that in implementing performance management required clear and measurable objectives and systematic of some elements both individual and group. Then there must be a mechanism to measure and evaluate the achievement of the objectives, both from the side of the results themselves, as well as the process of achieving the results reflected among others from the attitude and employee behavior. For that an organization should focus on managing the organization that includes the objectives and can be predicted or described and linked to the goals of the organization widely. According to Wibowo, (2016: 20), performance management concerned with human resource management issues in the organization into input, performance implementation process, output or performance results and the benefits or impact of a performance can be explained as follows:

1. Input, performance management requires input in the form of human resource capability, both individuals, and as a team, human resource capability is manifested in the form of knowledge, skills, and competence. Mansuai resource is the main source of input because with the existence of competent mansuai resources then the goal of an organization will be achieved well.

2. Process, performance management includes a process of performance execution of how performance is performed that begins with planning and preparing existing human resources and its management can be implemented properly. In the process, a measurable business process is in place for the organization to proceed as expected. 


\section{Macrothink}

International Journal of Human Resource Studies

ISSN 2162-3058 2018, Vol. 8, No. 1

3. Output, without any output then the performance will not produce maximum performance results, therefore the performance management is very related to the output which is the result of an organization, for it not only output but the output must be able to bring the results and the impact for progress organization.

4. Benefits, whether inputs, processes and outputs do not make the organization successful but must be results-oriented and beneficial, with the benefit that the organization can take steps to anticipate and plan the next performance whether it will be improved or there is in-policy policy that hampers organization.

\subsection{The Basic Principles of Performance Management}

In managing performance management there must be mutual agreement in management through the basic principles that serve as a reference or guidance in achieving organizational goals. The basic principles in performance management according to wibowo (2016) are: 1) Strategic, 2) Holistic, 3) Integrated, 4) Formulation of objectives, 5) Planning, 6) Feedback, 7) Measurement, 8) Performance improvement, 9) Sustainable, 10) Creating culture, 11) Development, 12) Honesty, 13) Ministry, 14) Responsibility, 15) Consensus and Cooperation, 16) Two-way communication, 17) Share hope, 18) Managing Behavior, 19) Playing and 20) Pity.

Management by applying these principles will be able to produce an organization that can be compiled and executed from planning to the goal to be achieved and continuously evaluated so that between each other fellow members can be harmoniously intertwined.

\subsection{Stages of Performance Management}

The success of a performance is preceded by good planning, which begins with the preparation of strategic planning of an organization that is by setting the main goals of the organization. With this planning then the organization must be able to determine what should be done in achieving organizational goals that are described at the level of the units work under it.

In the strategic planning must pass through several stages to describe the planning process that are:
a. Define the purpose.
b. Define the scope of the product or jaa.
c. Assess internal resources.
d. Assessing the external environment.
e. Analyze the internal settings.
f. Assessing competitive advantage.
g. Develop a competitive strategy.
h. Communicate strategies with stakeholders.
i. Implement strategy.
j. Evaluate the benefits. 


\subsubsection{Goals and Objectives}

In achieving the goals and objectives it must be determined the vision and mission of the organization where what must be achieved and in what way the organization will be executed it must be set clear vision and mission. Objectives are the direction of the general direction, where the organization will take place, the goal can be defined as what is expected to be achieved by an organization, functions, departments and individuals within a certain period of time.

\subsubsection{Performance Agreements}

Performance agreement is a performance contract between an employee or a worker with a manager called a contractual person, in which both parties agree on the goals and objectives to be achieved and part of the commitment to achieve the objectives. The existence of such performance contracts can be seen and elaborated on what the organization expects through the manager and which is the responsibility to be carried out and what size is the expected performance assessment.

\subsubsection{Performance Planning}

In an effective organization, work is planned from the beginning where at this stage a complete Key Performance Indicator (KPI) is established with the various strategies and work programs needed to achieve the desired performance. This KPI should be measured quantitatively and clearly its deadline. This measure should also be able to answer the various problems faced by the organization / company. The objectives set must meet the SMART criteria: Specific, Measurable, Achievable, Result oriented, and Time related. From the ideal performance planning process it must be able to produce outcome or result or benefit so that the result to be achieved is aligned with organizational goals through development planning, planning time, responsibility manager, responsibilities of workers, action plan and performance standards.

\subsubsection{Performance Implementation}

After making good planning and the agreement in management then the next is to carry out organizational performance, the success of an organization in implementing the performance can succeed and even failed both caused by internal factors and external factors organization. For that must be built a conducive working environment as well as every element understand the performance undertaken so that goals together can be realized.

\subsubsection{Performance Evaluation}

In this process the evaluation of the achievement of the performance and objectives are determined and the results are used as feedback. This process is performed on every employee and every employee is entitled to know how their performance and management are obliged to notify them. From the evaluation results can be done Performance assessment conducted objectively involving various parties. Armstrong (1998: 194) explains that performance appraisals are not control or oversight activities, nor are they looking for faults to impose sanctions or punishments. The activities focused on disclosing the deficiencies in 
work to be improved and the advantages of working to be developed, so that every employer / employee knows the level of efficiency and effectiveness of his contribution in carrying out his work in order to achieve organizational goals.

\subsubsection{Reward and Punishment}

In an effective organization, rewards are used well. Respecting employees means acknowledging, individually and as a group member, for their performance and recognizing their contribution to the agency's mission. Reward \& punishment is given after seeing the results of performance realization, whether in accordance with key performance indicators that have been planned or not. Reward \& punishment can be used as a motivation to improve performance. Reward motivation is better than punishment. Reward and punishment not only in the form of financial but can also form other forms such as promotions, educational opportunities, etc.

\subsection{Application of Performance Management}

\subsubsection{Duties and Functions of the Inspectorate General}

The Inspectorate General is headed by the Inspector General who has the duty to exercise internal supervision within the Ministry of Law and Human Rights and is expected to improve its supervisory performance in relation to Quality Assurance in order to guarantee the quality of good supervision and supervisory results conducted on the target and objectives and in accordance with the provisions of the standards audit of the government internal supervisory apparatus to the public. In addition to providing good quality supervision guarantees, the Inspectorate General also carries out a consultation role so as to provide early warning to all organizations and work units to prevent and minimize the possibility of violations and irregularities. Based on the regulation of the Minister of Law and Human Rights No. 29 of 2015 on the organization and working procedures of the Ministry of Law and Human Rights of the Republic of Indonesia, the Inspectorate General has the duty to supervise the implementation of duties within the Ministry of Law and Human Rights of the Republic of Indonesia. In performing these duties the Inspectorate General shall perform the functions of:

1. Preparation of policy formulation of supervision;

2. Implementation of internal control through audit, review, evaluation, monitoring, and other supervision;

3. Implementation of administrative affairs of the Inspectorate General;

4. Preparation of supervision reports; and

5. Coordinating the implementation of internal controls, external supervision and or related law enforcement agencies.

\subsubsection{Vision of the Inspectorate General's Mission}

In line with the strategic change, the Inspectorate General as the Government Internal Supervisory Apparatus (APIP) at the Ministry of Law and Human Rights, is required to play a role as a quality assurance and consultant and guard the achievement of performance targets 
of work units within the Ministry of Law and Human Rights in accordance with their duties and its function to help realize good governance, accountability of quality financial statements, transparent, clean of collusion is the goal to be achieved.

These commitments are further set forth in the Inspectorate General's Vision: "Making Internal Supervision Unit independent, professional and integrity to increase public confidence in the performance of the Ministry of Law and Human Rights".

In the Vision there are some keywords that are independent, professional and integrity where independent can be interpreted that in carrying out supervisory duties if the Inspectorate General of the Ministry of Law and Human Rights perform the task independently / unaffected group or individual in decision making. Professionals can be interpreted that the resources of the supervisory apparatus must continue to be developed competence to work professionally all decision makers based on objective consideration. And in carrying out its duties are required to uphold integrity and become an example or role model and have a commendable value based on the values of honesty, diligence and responsible.

In implementing the vision described in the mission of Inspectorate General are:

1. Improving the accountability of duties and functions of the work units within the Ministry of Law and Human Rights, by realizing a predicate unit of the Free Territory of Corruption / Bureaucracy and Cleaning the Service Area;

2. Optimizing building the government's internal control system within the Ministry of Law and Human Rights;

3. Develop quality and quantity of human resources Inspectorate General;

4. Develop quality monitoring based on information technology;

5. Improved management support and technical support services.

The translation of the mission continues to be optimized by the Inspectorate General in order that its supervisory results have added value and benefits to the organization, especially the main stakeholder through the policy of supervision and main performance indicators (IKU) or KPI which is oriented to the outcome or result that is "Increased accountability of duties implementation and work unit function in environment of the Ministry of Law and Human Rights as follows:

\begin{tabular}{|c|c|c|}
\hline & Key Performance Indicators & Target \\
\hline \multirow{4}{*}{$\begin{array}{l}\text { Increased accountability of } \\
\text { duties and functions of work } \\
\text { units within the Ministry of Law } \\
\text { and Human Rights }\end{array}$} & $\begin{array}{l}\text { 1. Percentage of work units whose financial } \\
\text { management is in accordance with } \\
\text { government accounting standards. }\end{array}$ & $80 \%$ \\
\hline & $\begin{array}{l}\text { 2. Percentage of work units with } \\
\text { accountability for performance of "good" } \\
\text { category. }\end{array}$ & $80 \%$ \\
\hline & $\begin{array}{l}\text { 3. The number of predicated working units of } \\
\text { the region free from corruption (WBK) / } \\
\text { bureaucratic net serving area (WBBM) } \\
\text { within the Ministry of Law and Human } \\
\text { Rights. }\end{array}$ & $\begin{array}{l}12 \\
\text { satuan } \\
\text { kerja }\end{array}$ \\
\hline & $\begin{array}{l}\text { 4. Public satisfaction index on public services, } \\
\text { within the Ministry of Law and Human } \\
\text { Rights. }\end{array}$ & 7,24 \\
\hline
\end{tabular}


The monitoring program is set forth in the annual supervisory program (PKPT) conducted through several programs and activities, among others through review of financial reports and budget absorption reviews, performance audits, financial management audits and audit of goods and services, performance evaluation, intensification of community complaints handling, whistle blowing system and self-assessment assessment of bureaucracy reform and implementation of integrity zones to areas free from corruption / bureaucratic clean and serving areas.

\section{Discussion}

\subsection{Implementation of Competency Based Performance Management System at Inspectorate General of the Ministry of Law and Human Rights}

\section{a. Performance Planning}

Performance planning is a starting point in the process of performance management system at the Inspectorate General of the Ministry of Law and Human Rights. This can be seen in the presentation of data that in the performance planning has been determined assessors and employees assessed in stages adjusted to the work procedures that regulate the aspects of coordination, task, authority and accountability of each work unit. Where assessed officials and assessed employees work together to establish Individual Performance Goals (SKIs) by identifying, understanding and agreeing on the targets to be achieved by the assessed employees, the competencies to be achieved by the assessed employees, and methods for assessing employee performance rated. Establishment of targets to be achieved by the assessed employees refers to the RKAP set by the board of directors and commissioners and / or assignments of the Board of Directors, and the competence to be achieved by the employees assessed shall refer to the Job Competency Requirement (KKJ) held by the employees rated. As for the method of assessment must be fair and contains criteria that will be used to assess the performance of employees assessed at the end of the period. According to Williams in Dharma (2004: 30) that the objective should be to support the company's overall strategy so that the common goals can be integrated and consistent, and the need to establish the actual levels of achievement, so that the basis for performance appraisal can be clearly understood. The results of the performance planning are mutual understanding and agreement on the goals, objectives, performance standards and competency needs written through the Individual Performance Target (SKI) form and approved by both parties, which then become the work plan of the assessed employees for one year. According to Williams the setting of performance goals is also a process that ensures that every employee understands the targets to be achieved to maximize their contribution to the company, and goal setting allows employees to know what is required for them and on what basis their performance and contribution will be assessed. The performance planning process is based on the determination of the Individual Performance Goal (SKI) through an agreement between the assessing officer and the assessed employee at the beginning of each year in January.

b. Performance Communication, Guidance, and Documentation

Performance communication, guidance, and documentation is a problem-solving process by 
communicating it and identifying the true underlying cause of the problems or performance failures that can be formulated to solve the problem. According to Bacal (2001: 35) continuous performance communication will make way for managers and employees to work together to prevent problems, solve problems, and improve performance. Things that happen in the field too. The implementation of performance communication, guidance and documentation at the Inspectorate General of the Ministry of Law and Human Rights proceeds with a continuous and continuous two-way communication process between appraisal officials and assessed employees to ensure that the implementation of agreed work targets runs properly, communicates identification obstacles that arise and discuss how to solve them, and give each other up to date information about what they need in order to achieve performance success. In this process, the assessment officer acts as a mentor who can provide guidance to help develop the employee's knowledge and expertise assessed in the problem-solving process and support the performance improvement of assessed employees. Handy in Dharma (2004: 28) also states that in a performance management system can help managers become teachers, mentors and friends who are more than just leaders, trusting employees to use their own methods to achieve what managers expect, and understand every problem can be overcome by developing the capacity of others to overcome them. The results of the communication process and guidance in the form of records that need to be documented on the guidance form as refrentions that are beneficial for performance improvement, and support the achievement of agreed performance targets in the Individual Work Goal form. This is also in line with Bacal's (2001: 37) assertion that the results of the documentation are records that need to be stored to support the achievement of agreed targets. Ensure that the records provide benefits and have a positive impact on the achievement of agreed targets.

\section{c. Performance Evaluation and Evaluation Process}

Performance appraisal is the stage that determines whether the appraisal officer or the assessed employee has succeeded in showing the performance that matches the intended target or not. Thereafter, a performance evaluation will be conducted that enables assessors and employees assessed to cooperate to identify the deficiencies found so that they cannot achieve the stated objectives, and then improved in the next performance plan. It can be seen in the presentation of data that the application of performance appraisal in Inspectorate General of the Ministry of Law and Human Rights is done through the completion stage of Performance Evaluation Form (PAK) by appraisal officer. Where an appraiser officer provides an assessment of the work performance of an assessed employee by comparing between the target plan and the competencies specified in the SKI or guidance and agreed upon by the realization at the end of the assessment period. Final Performance Assessment was conducted in January of the following year. Assessment criteria include the achievement of targets and the achievement of the required competencies during the period of January of the previous year. The process is in accordance with the explanation of Mondy (2008: 260) in the performance appraisal process that at the end of the appraisal period, appraisers and employees together assess performance in the work and evaluate it based on predetermined performance standards. The appraiser officer may then write his opinion as an evaluation of 
the performance of the employees assessed in the appraisal officer's recommendation column as stated in the Performance Evaluation Form (PAK). This is consistent with Kreitner \& Kinicki's statement in Wibowo (2011: 262) that performance evaluation is an evaluative opinion of the person's nature, behavior, or achievement as the basis for personnel development decisions and plans. The results of the final assessment as outlined in the Performance Appraisal Performance form are distributed to appraisal officers, assessed employees and the Personnel Department. Where the Performance Evaluation Form (PAK) form further becomes the basis for determining the HR management policy by the Personnel Department, which includes: placement, promotion, career planning, training needs and employee development, and remuneration.

\section{d. Concept of Application of Competence in Performance Management System}

Competence is what employees need to do their work in the form of different types and levels of behavior. The identification of this type of behavior and behavioral type is differentiated from the skills, knowledge and skills required to perform various tasks related to the job. Based on the presentation of data, the process of identifying competencies in the performance management system in the Inspectorate General of the Ministry of Law and Human Rights is done by top down arrangement, starting from the vision and mission which is translated into the values and strategy of the Inspectorate General of the Ministry of Law and Human Rights. In harmony with these basic values and strategies, it is explored and formulated the core competence (Corporate Core Competence). Corporate Core Competence is then translated into soft competence and hard competence. Soft competence is a competence that consists of motives, properties and self-concept, which required someone to produce superior performance. While hard competence is a competence consisting of knowledge and skills needed by a person as a minimum requirement to be able to work effectively, but has not resulted in such individuals having superior performance. Hard competence is downgraded to core hard competence which is a core competency that must be owned by all functions in the organization, and supporting hard competence (competence field) which is the supporting competencies required by certain functions within the organization. The combination of core competence and supporting competence is called corporate competence. This is in accordance with the statement from Wibowo (2011: 334-335) which explains that competencies are grouped into core competencies which are core competencies associated with corporate strategy that should be owned by all employees in the organization, managerial competencies which is a competency that reflects the managerial and the performance required in a particular role which can demonstrate the ability to run management and functional competencies that are competencies that explain the specific role capabilities required and are usually associated with professional or technical skills. After that, the preparation for the Job Competency Needs (KKJ) and Individual Competency Needs (KI) in each type of competence is conducted by way of job analysis to identify the scope of work to determine the type and level of competence required. 
4.2 Factors Supporting the Implementation of Competency Based Performance Management System at the Inspectorate General of the Ministry of Law and Human Rights

Factors that support the implementation of a competency-based performance management system at the Inspectorate General of the Ministry of Law and Human Rights is the awareness of every employee to always discipline collecting the form of Individual Performance Indicative (SKI) forms, Guidance form and Performance Evaluation Form (PAK) personnel in accordance with the specified time period. In addition, the involvement of each individual employee to be able to complete each note of its performance well in accordance with the rules of filling the form of reporting that has been set. Each individual employee as an appraiser officer or an assessed employee must cooperate in establishing a performance agreement starting from setting Individual Performance Goals (SKI), preparing guidance reports, and Reporting Performance Appraisal. However, based on observations of things happening in the field is not the case? Still no specific attention from employees, there are still many employees who fill the form with copy, paste and undisciplined in collecting PAK form. Based on this, it can be concluded that employees have not fully supported in some of the process of this performance management system. It still needs awareness, discipline, and involvement in every process. According to Dharma (2004: 29) the process of performance management is a partnership between managers and individuals where at each stage the objective is to reach agreement on the objectives and requirements of expertise and competence, on the assessment of the results and the factors that influence it, and the development plan and performance improvements. If the process is not fully supported by the employee, then surely the maximum benefit will not be obtained from this process. Because to get the maximum profit, need to carry out the process as a whole, not just one part only.

\subsection{Factors Inhibiting the Implementation of Competency Based Management System at the Inspectorate General of the Ministry of Law and Human Rights}

Factors that impede the application of competency-based performance management system to the Inspectorate General of the Ministry of Law and Human Rights are the objectivity of the appraisal officials in Providing Performance Appraisal. Appraisal officials often provide non-factual assessments in the field, but based on an appraisal of the assessor's personal relationships with assessed employees. This has resulted in the performance management system management team having difficulty identifying employees who have superior competence and employees with ordinary competence. It also affects the process of determining HR management policies by the personnel department, which includes placement, promotion, career planning, training needs and employee development, as well as payroll or remuneration. Performance appraisal must, of course, be based on the realities of the employee's performance in the field, not influenced by any element that may result in the objective assessment result. In accordance with the statement by Dharma (2004: 79) which states that employee performance appraisal should be rooted in the reality of employee performance that is real, not abstract, which allows managers and employees to take a view on how performance can be better and how problems arise can be solved to meet performance goals.

Based on several theories and programs of supervisory activities undertaken at the 
Inspectorate General, according to our analysis, the Inspectorate General has implemented performance management in order to cope with organizational and technological developments which have been implemented in the Inspectorate General whether activities undertaken for guidance at the central and regional levels as well as internally The Inspectorate General itself is as follows:

1) Creation of a shared meaning or vision of goal-oriented objectives or outcomes that is "increased accountability execution of tasks and functions of work units within the Ministry of Law and Human Rights. With the vision of the Inspectorate as an internal control apparatus in the ministry of Law and Human Rights, it is "Making Internal Supervision Unit independent, professional and integrity to increase public confidence in the performance of the Ministry of Law and Human Rights" which means each technical unit or in the management or secretariat shoulder to shoulder to carry out the task by exchange of information either through activity of morning copy or routine meeting held on Monday giving information exchange.

2) Each performance produced has been measured with clear indicators then each individual must be able to achieve the targets that have been established through several activities and monitoring programs to stakeholder. So that in 2016 has been proposed to the Ministry of State Apparatus Empowerment that as many as 25 units of work have been proposed to be a predicated work unit WBK one of them is Classification Correctional Institution IIA Semarang.

3) Performance evaluation in an orderly manner through e-performance where each employee fills in on the performance target set by e-performance.

4) Employee performance goals. Performance that has been implemented must be monitored through 2015 new "simpeg" where every employee either from the lower level up to the manager for SKP / Target Employees who exist in one element in the Performance Assessment of civil servants in accordance to government regulation (PP). No. 46 Th. 2011 by keeping a journal every day.

5) Remuneration allowance. Based on the regulation of the Minister of Justice and Human Rights of the Republic of Indonesia number 5 of 2015 on the amendment to the Regulation of the Minister of Law and Human Rights No. 22 of 2014 on the implementation of the provision of performance allowance for employees within the Ministry of Justice and Human Rights, employees have received performance allowances but not yet clearly the size of its performance is still based on the attendance list of employees

\section{Conclusion}

Performance management has a very strategic role as a medium for organizations to perform results-oriented oversight tasks and in accordance with the expected goals and synergize between employees and managers by not leaving on the values of honesty. In applying performance management, companies can use Reward and Punishment as a motivation to improve employee performance.

The pattern of human resource management in the Inspectorate General of the Ministry of Law and Human Rights implements Competency-Based Human Resource Management 
(CBHRM) which is implemented in various aspects ranging from recruitment, training, career planning, including in the application of its performance management system . Achieving the company's vision, mission, values and strategy is the goal of CBHRM implementation as a whole. Based on the organizational structure that has been formed can be formulated job descriptions of each element of the structure and identified the need for competence for each position. The requirement of office competence is used for each stage of human resource management process including the process of performance management system. The implementation of the performance management system process in the Inspectorate General of the Ministry of Law and Human Rights is itself a process to create a common understanding between the appraiser officer and the employees assessed on what to achieve (Key Performance Indicator of the company / Key Performance Indicator individuals), and how to achieve them and their assessment methods.

\section{Suggestion}

In applying performance management, the Inspectorate General as a supervisory unit to be an example to other units so that performance can be measured and clear not only based on absences so that the performance of the Ministry of Justice and Human Rights runs according to the organization's objective of providing services to the community well.

\section{References}

Armstrong, M. (2006). A Handbook of Human Resource Management Practice. 10th Edition. London and Philadelphia: Koagen Page.

Armstrong, \& Murlis. (2009). Reward Managemen, Hay Group.UK.

Costello, \& Sheila, J. (1994). Effective Performance management. New york: Mc Graw-Hill Companies,inc.

Dharama. (2005). Manajemen Kinerja, Falsafah, Teori dan Penerapannya. Pustaka Pelajar. Yogyakarta.

Inspektorat Jenderal Kementerian Hukum dan HAM. (2015). Renstra Kementerian Hukum dan HAM 2015-2019.

Kementerian Hukum dan HAM. (2015). Peraturan Menteri Hukum dan HAM No. 29 Tahun 2015 tentang Organisasi dan Tata Laksana Kementerian Hukum dan HAM.

Lockett, J. (1992). Effective Performance Management: A Strategic Guide to Getting the Best from People. Kogan Page.

Miles, B. M., \& Michael, H. (1992). Analisis Data Kualitatif Buku Sumber Tentang Metode-metode Baru. Jakarta: UIP

Moleong, L. J. (2007). Metodologi Penelitian Kualitatif. Bandung: Remaja Rosdakarya.

Peraturan Pemerintah No. 46 Th. 2011 tentang prestasi kinerja pegawai negeri sipil.

Peraturan menteri hukum dan hak asasi manusia republik Indonesia nomor 5 tahun 2015 tentang perubahan atas peraturan menteri hokum dan hak asasi manusia nomor 22 tahun 2014 


\section{Macrothink}

International Journal of Human Resource Studies

ISSN 2162-3058 2018, Vol. 8, No. 1

tentang pelaksanaan pemberian tunjangan kinerja bagi pegawai di lingkungan kementerian hukum dan hak asasi manusia.

peraturan menteri pendayagunaan aparatur negara dan reformasi birokrasi republik indonesia nomor 11 tahun 2015 tentang road map reformasi birokrasi 2015-2019.

Tampubolon, M. (2008). Perilaku Keorganisasian Edisi Kedua. Jakarta: Ghalia Indonesia.

Wibowo. (2017). Bahan mata kuliah, performance management (manajemen kinerja) buku I. Universitas Negeri, Jakarta.

Wibowo. (2016). Manajemen Kinerja Edisi 5. PT. Raja Grafindo Persada, Jakarta.

\section{Copyright Disclaimer}

Copyright for this article is retained by the author(s), with first publication rights granted to the journal.

This is an open-access article distributed under the terms and conditions of the Creative Commons Attribution license (http://creativecommons.org/licenses/by/4.0/). 